\title{
VANILLA PLANIFOLIA, THE FIRST MESOAMERICAN ORCHID ILLUSTRATED, AND NOTES ON THE DE LA CRUZ-BADIANO CODEX
}

\author{
Luis D. Gómez P. \\ Academia Nacional de Ciencias, Costa Rica \\ Apartado 676-2050, San Pedro, Costa Rica \\ gomezp@ots.ac.cr
}

\begin{abstract}
Abstract. The Codex Barberini lat. 241 or Codex Badianus is a manuscript by Martín de la Cruz, entitled Libellus Medicinalibus Indorum Herbis and the first New World herbal, written in 1552. It includes 249 medicinal plants of which only 184 are illustrated. Among the plants depicted is tlilxochitl which is the Nahuatl name, even to this day, for Vanilla planifolia Andrews. Thus, the illustration of that plant in the Codex constitutes the first illustration of a Mesoamerican orchid done for European readers and antedates the publication of the genus and its species by two centuries. Some new historical aspects of the Codex are presented.
\end{abstract}

Key words: Vanilla, tlilxochitl, Codex de la Cruz-Badiano

The situation and conditions of the indigenous peoples in the early colonial times in the New World were of hopelessness and brutality. An extraordinary figure appears in Bartolomé de las Casas (1484 1566), considered by many as the father of anti-imperialism and anti-racism who, in 1520 , presented a defense of the Indians to Emperor Charles V. In 1523 he commenced writing his Apologética historia de las Indias and Historia de las Indias (the latter not to be published until 1875!) and, finally, in 1542 he succeeds in obtaining from the Emperor the promulgation of the Nuevas Leyes prohibiting slavery, the beginning of the end for the infamous systems of "encomiendas", and promotes the proper education of Native Americans. In 1543 las Casas published his demolishing denunciation of the Spanish exploitation and barbaric cruelty, $L a$ Destrucción de los Indios.

The sadness of those events have been treated by many authors. Of import for these notes Keen (1999), Pincherle (1952), Somolinos (1964), Viesca (1992). Whether with or without new laws, the Spanish settlers and the criollos born in the Americas, maintained a disdain for things indigenous, and it is sad to admit that those sentiments of inequality still prevail in many parts of Latin America. But de las Casas influenced many others in positions of power, both secular and ecclesiastical.
It was in that atmosphere that under the auspices of the Viceroy of New Spain, Antonio de Mendoza and the Bishop of Mexico Juan de Zumárraga, both in favor of the protection of the Indians and scarcely thirty years after the fall of Tenochtitlan, that the Colegio de Santa Cruz de Tlatelolco, was founded in 1536 by the Franciscan friars thus becoming the first institution of higher learning in the continent (Borgia, 1944). However, Viceroy Mendoza was transferred to Perú and Bishop Zumárraga died in 1548. The Colegio taught Nahuatl, Latin, Greek as well as crafts such as illumination, bookbinding and other European arts to the descendants of the Aztec nobility and other principal people. Among its first teachers were some important figures in the recording of Mexican ethnography, anthropology and Nahuatl literature: Alonso de Molina, Andrés de Olmos, Bernardino de Sahagún. Even fray Juan de Torquemada, himself a fine historiographer, unfortunately later linked to the Inquisition, was a professor at Tlatelolco. As a student was one Juan Badiano and in some capacity a native healer, Martin de la Cruz, both from Xochimilco. Mason (2004) says both were convert priests while others supposed them both to be medics but we know nothing about these two individuals.

As the opposition and ill-will of the peninsulares and criollos toward the Indians and the Colegio persisted, 
Antonio de Mendoza's son, Francisco, requested that a compilation of local healing practices and herbs be produced for the King of Spain, by now Phillip II, son of Charles V, in another effort to demonstrate that the Indians were knowledgeable, capable of learning from Europeans and very worthy of support from the Viceroyalty and the protection of the King. Martin de la Cruz was commissioned to produce the volume and Juan Badiano was charged with its translation from Nahuatl into Latin. That is the origin of the Codex. The administration of the Colegio was given to the native Franciscans in 1554, financial support from government sources stopped in 1606 and by the middle of the $17^{\text {th }}$ century the Colegio de Tlatelolco ceased to exist. For more on its history Somolinos $(1964,1996)$.

The original text in Nahuatl has disappeared but the project was under the tutelage of friar Jacobo de Grado, superior of the convent and the Colegio, who did oversee the production and translation of the manuscript for Francisco Mendoza who had it sent to Phillip or possibly took it himself to the court in Madrid (Goodman 1990, Martínez 1994) and the Codex must have been in the royal library at El Escorial at least until the $17^{\text {th }}$ century, and forgotten. That is until it was found in the possession of don Diego de Cortavila y Sanabria, Apothecary to the King and founder of a medicinal plant garden on the palatial premises, as well as developing one of his own. The Codex was later obtained by Cardinal Francesco Barberini who was sent as Nunzio to Spain by his uncle Maffeo Barberini who was pope Urban VIII. The Cardinal was an avid bibliophile with a penchant for Americana, specially early texts, and he incorporated the Codex into his library.

There has been much doubt as to how the codex passed to Cortavila. Martínez Millán (1994) supposes that it was given by the Infanta Juana to the Convento de las Descalzas Reales which she had founded. Juana, youngest sister to Philip II, governed Spain in his absence and actually met with Francisco Mendoza to discuss, among other things the "capitulaciones" or agreements concerning for the commerce of medicinal plants between Spain and Nueva Espana. Cortavila was the pharmacist for Juana and all members of the royal house which also included Infanta Margarita de la Cruz, a niece of Juana and also a nun at said convent, who might have presented her apothecary with the Libellus as an appropiate gift to a renowed herbalist. The frontispiece of the Codex bears a hand written inscription "ex libris didaçi Cortauila", this book belongs to Diego Cortavila.

One could easily suppose that Cortavila, very much in the favour of the King had access to the royal library and its massive and mostly uncatalogued treasures and decided to keep it for the better practice of his métier? In any case, Cortavila did not promote the Codex among his learned acquaintances and seems not to have been particularly interested in the Mexican manuscript. Otherwise, his close friend and collaborator Bartolomé de Cienfuegos, pharmacist, bibliophile and fine grower of herbs would have mentioned it in his careful notes (Arévalo 1935, Rey 2004).

How it came to the hands of Barberini has been another mistery. His Eminence bought many things from many people being a patron of the Arts and Sciences. Did he also buy the Codex or pushed his ecclesiastical weight to obtain it? The recent publication of the personal secretary and factotum to the Cardinal, Cassiano dal Pozzo's, detailed and meticulous notes of Barberini's trip to Spain (Anselmi 2006) solves the problem. The entry for June 26,1626 records a visit of Barberini and his retinue to Cortavila's botanical garden where the pharmacist presented His Eminence with "un libretto di Semplici diversi Indiani con le sue figure, e virtu appropiate alla maggior parte dell'l' indispositioni di corpi humani". Barberini simply walked away with a precious gift. What then?

Francesco Barberini founded the Vatican Library in 1679, not long before his death, but he was also an illustrious member of the Accademia dei Lincei, so respected that at the demise of its patron founder Prince Federico Cesi, the Cardinal was suggested as his successor. (Gabrieli 1880).The Accademia, as most cognoscenti in Europe, was enthralled with the exotic new things from the New World (Guerrini 2008) and was contemplating the publication of a materia medica prepared by the Neapolitan physician Nardo Antonio Recchi, based on Francisco Hernández de Toledo's Rerum medicarum Novae Hispaniae Thesaurus, the Tesoro Messicano. One would think that Barberini would have promoted the manuscript in his possession as an equal candidate but he did not, or there is no evidence that he tried. 
However, diligent dal Pozzo, also a member of the Lincei had a quasi-facsimilar copy done by the painter Vincenzo Leonardi of Grimignano in the winter of 1626-27 (Mason 2004) and that copy became known to many people after it was used as a pictorial source of Mexican flora to accompany the illustration of Mexican fauna and a first version of Hernández' Rerum, in Johan Faber's Animalia Mexicana descriptionibus scholjistique exposita, thesauri rerum medicarum novae hispaniae, published in Rome in 1628 with the beneplacito of the Lincei. That is the copy that eventually Pozzo's heirs sold to pope Clement XI who in turn sold it to his nephew Cardinal Alessandro Albani who in turn sold it to George III of England (Byland 2000) and it is now in the Royal Library at Windsor Palace. It is stamped with dal Pozzo's Coat of Arms. Another quandary solved.

It has been suggested that a second copy might have been done for Francesco de Stelluti, with Cesi, van Heeck and de Filiis one of the founders and Consigliere Maggiore of the Accademia, but if so it is lost. Why would Stelluti, the author of Melissographia, the first anatomical description of insects under Galileo's microscope, wish for a copy? Because he was charged by Cesi with the edition of the Tesoro Messicano, on which he worked in close collaboration with dal Pozzo. In the original plan for this edition, Barberini was the dedicatee but when the Cardinal was banned from Rome in 1644 by pope Innocent X, Barberini's name was deleted. The final edition by the Lincei appeared in 1651 .

Incidentally, the work of Hernández, may be considered as a report of the first scientific expedition to the New World in 1571 and was translated into Spanish by friar Francisco Ximénez and published in México in 1615.

And what of the original Codex? It rested forgotten and ignored in the shelves of Barberini and later, when the entire Barberini collection, some 60000 plus items, was incorporated into the Vaticana by pope Leo XIII in 1902 (Major 1931), it rested under the signature Barberini lat. 241, forgotten and ignored a few more decades until a student of the Barberini entries, Charles Upson Clark, a historian of early American medicine at the Smithsonian Institution, discovered it and announced it to the world in 1929. According to Sharp
(2005) Clark brought the manuscript to the attention of Dr. William Welch at Johns Hopkins University and Welch's interest prompted the first facsimilar edition by Emmart. León Portilla (2002) writes in error that the discovery dates to 1925 and was almost simultaneous by Clark, Giuseppe Gabrieli an erudite Lincei y Lynd Thorndike, a historian of science. To León Portilla's commentary I must add that Gabrieli did not discover the original Codex but the dal Pozzo copy at Windsor (Gabrieli 1929), Lynd Thorndike was in Rome trying to enumerate and describe the contents of the Barberini collection dealing with the history of science and obviously listed the Codex among the items (Thorndike 1929-1930). The true date of discovery remains as 1929 . The original de la CruzBadiano manuscript was returned to Mexico by pope John Paul II in 1990 (Durazo et al. 1991).

After its discovery by Clark there have been several facsimilar editions of the de la Cruz Badiano Codex as I the Libellus should be justly known: The W. Gates edition of 1939 as The de la Cruz-Badiano Aztec Herbal (Publications 22, 23 of the Maya Society, Baltimore) which does not reproduce the illustrations in color, the Emily Walcott Emmart edition of 1940, The Badianus manuscript (Codex Barberini, Latin 241). An Aztec herbal of 1552, published by Johns Hopkins, the edition by the Instituto Mexicano de Seguro Social in 1964, followed by the Fondo de Cultura Económica in Mexico in 1991 with a second printing in 1994, reprinted in 1996 which is the one I own, all as Libellus Medicinalibis Indorum Herbis. Francisco Guerra, a physician in Mexico who has written much about pre-Columbian medicine, published an edition without pictures in 1955, being the first translation into Spanish. In 2000 the publishing house of Dover has produced a new facsimile of Gates' edition. For more on other editions and versions $c f$ Somolinos (1996).

The Codex has been described in the editions mentioned above and by Robertson (1959), Fernández (1964) and Stolz (1964). It was written in a format slightly smaller than quarto $(15.2 \times 20.6 \mathrm{~cm})$ on European paper, as per the watermarks from the mill of Basili Accinelli of Genoa whose paper was rather frequent in the colonial New World, the folios sewn into eight quires or booklets, bound in red velvet with a six cords spine. The inks are ferric gall for the text 
and elsewhere and for the red rectangle created on each page a minium gall ink (Zetina et al 2008). The calligraphy is cancelleresca. The text is in a Latin of Pliny's style, and although sufficient it nevertheless conveys the feeling that Badiano may not have been the most advantaged pupil of the Colegio. The folios are numbered in the upper right corner only of the front or recto of the page, the verso is not. The paintings are a fine example of syncretism of Renaissance style expressed through Aztec canons. Throughout several pages are blank. The text is organized in thirteen chapters, each dealing with medical conditions thought by de la Cruz to be somewhat related.

The botanical aspects of the Codex have been very poorly treated by Gates (1939) and very well by Emmart (1940), Reko (1947), Miranda and Valdés $(1964,1996)$. It is the last entry of Chapter 10, that has caught my attention (Fig.1).

The verso of page 56 shows the paintings of four plants: mecaxochitl, tlilxochitl, hueynacaztli and copalxochitl. The depiction of the first two is somewhat confusing because the artist has chosen to show the plants intertwined. The second root system corresponds to tlilxochitl. Under the drawings is a title followed below by the materia medica for the plants illustrated, which read;

\section{Viatoris presidium.}

"Dessicatiflores mecaxochitl, tlilxochitl, hueynacaztli, arborum copalxochitl et atoyaxocotl cortices, folia srboris axocotl, albus tus, ceratum xochiocotzotl, et yolloxochitl ita terantu ut puluerunt; puluerasta uero intra notissimi et fragantissimi floris huacalxochitl concauitatem ponito, quo huius floris odorem redolentissimum capiant, spirentque. Postremo laudatissimum florem yolloxochitl tamdem accipito quem decenter excauato, cuius factae concauitati salutiferum punisculum condito, uasculam collo suspendito"

Which I freely translate as:

For the traveller a protection.

"[The] dried flowers of mecaxochitl, tlilxochitl, hueynacaztli [and] the barks of the trees copalxochitl and atoyaxocotl, leaves of the tree axocotl, white incense, [the] wax of xochiocotzotl, and yolloxochitl [all together] pound to a fine powder. Once powdered put into the cavity of the showy and very fragrant flowers of huacalxochitl, as in there the scents will intensify and [are] trapped the odours [of that flower]. All that done, one of the much-praised flowers of yolloxochitl is taken which has a concavity in its center, and in this hollow the salutiferous powder [is] put [and that] little basket is suspended from the neck [of the traveller]"

It is, rather than a remedy for specific diseases of travellers, a charm to keep the traveller from potential harm and reminds one of the amulets, talismans and similar trinkets worn around the neck in the Middle Ages to avoid contagion. The word presidium, instead of the correct praesidium, is one of the many examples of Badiano's faulty Latin.

The second plant is illustrated without flowers but with its pods (vainillas, or small pods) and corresponds to Vanilla planifolia still called tlilxochitl, meaning "black flower" by today's Nahuatl speakers and it is the only orchid mentioned in the Codex.

Mecaxochitl or "plant of the strings" is an species of Piper as many of them are called "cordoncillos"; hueynacaztli or "large ears" was thought by Emmart and Reko to represent Cymbopogon penduliflorum (Dunal)Baill., a species with pendulous flowers on long pedicels, characters hard to be missed by keen native observers. I interpret it as Enterolobium cyclocarpon (Jacq.) Griseb., its fruits resembling big ears and, furthermore, the illustration suggests mimosoid flowers to me. This species is known as guanacaste in many parts of its range. Copalxochitl or "flower of copal" corresponds according to Reko to Cyrtocarpa procera Kunth could be any of the plants that yield aromatic resins or latices (Stross 1997, Langenheim 2003); axocotl or "fruit of the water" Reko identifies this as Spondias purpurea L., and atoyaxocotl or fruit of the river could refer to Pachira aquatica Aubl., much used throughout its range as an aromatizer. Xochiocotzotl, qualified by ceratum, is the gummy resin or turpentine from Liquidambar styraciflua L. or even from Pinus spp. (Breedlove \& Laughlin 1993). Yolloxochitl or "flower of the heart" is Talauma mexicana (DC) G.Don (53v); huacalxochitl or "flower in shape of a 


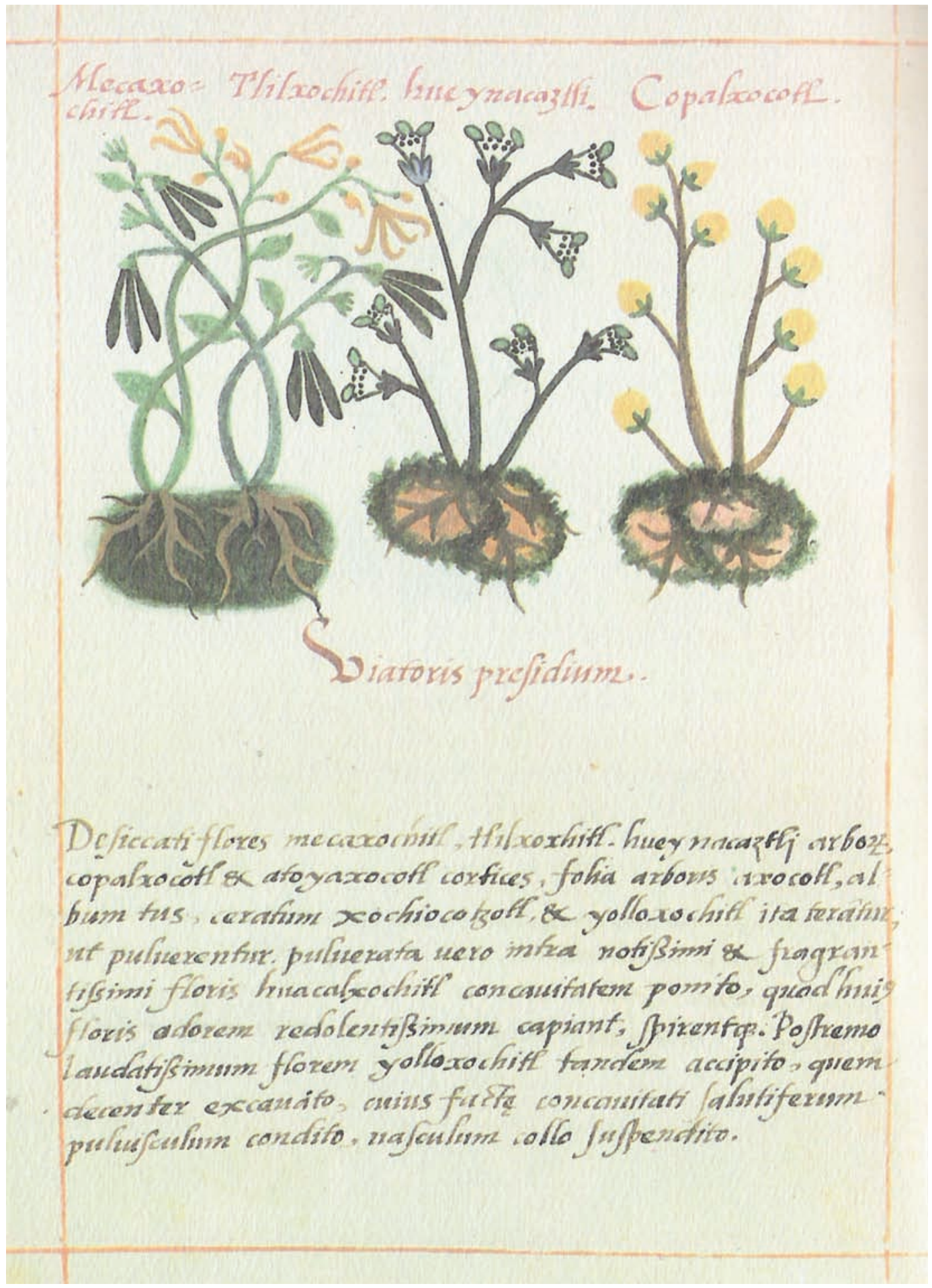

Figure 1. Page 56 verso. of Libellus Medicinalibus Indorum Herbis, the de la Cruz-Badiano Codex. The second plant (left to right) is tlilxochitl, Vanilla planifolia Andrews, the first depiction of a Mesoamerican orchid. 


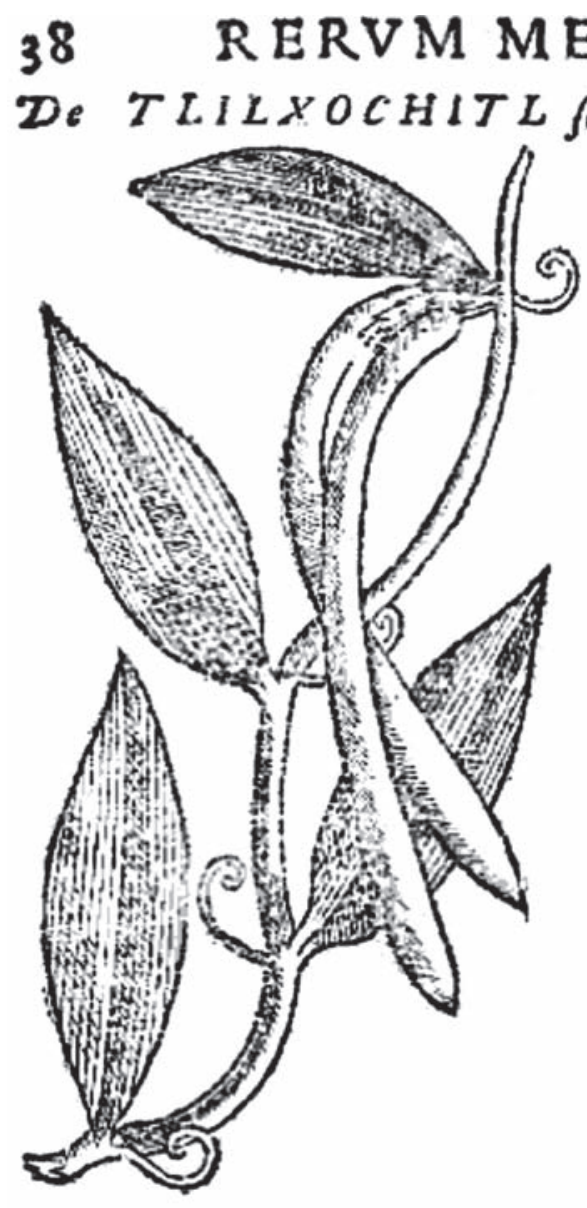

DICARVM NO. HISP.

De TLILXOCHITL feu fore nigro A raco Aromatico. Cap. $X V$. DOLVBI LIS herba eft Tlilxocbitl, fo. $\checkmark$ lijs Plantaginis prędita,fed pinguioribus, \& longioribus, viroreq. infectis facurato, fingu. lis ex veraque parte caulis alternatim exorient. bus;ac filiq̨uis longis,anguftis, \& penè teretibus, olentibus mutcum, aut Balfamum indigenum, nigrisq.vnde nomen.Calidis regionibus prousnit,huméribusq. Arbores amplectitur, \& prodictas filiquas verno tempore profert. Calid $x h x_{\text {, }}$ funt ordine tertio, addiq. Folitx Cacaostl, \& Mecaxochisl. filiquax bin $x$ ex aqua refolutx, \& porata vrinam cient, menltrua euocant . cum Mecaxochitl partum accelerant, ac fecundas, mortuumq. fotum trahunt, ventriculum ca. lefaciunt, \& roborant, flatum difcutiunt, lus. nores crudos concoquunt, arque attenuant, ccrehrn vim addınt, \& vrero auxiliantur. Aduerfus venena frigida, gelidosq. venenatorum jectus, cxdem filiquax dicuntur effe remedio.

Folium longuzen eff vncias vndecim, latum fext, fliqua verolonga vncias fex,eraßa digitum vnum

Figure 2. Tlilxochitl, Vanilla planifolia, in Hernández's Rerum Medicarum...Liber Secundun. Aromata Promit, Rome 1651, p. 38.

huacal" (or a vessel) is that of a species of Araceae, e.g. Philodendron with dentate or lobed leaves as it is illustrated elsewhere in the Codex. (18v). For the synonymy of Nahuatl words see Díaz (1976) and Garibay (1996).

The genus Vanilla Plum. ex Mill. was described in 1754 (Gard. Dict. Abr. (ed.4), 3. 1754) based on Charles Plumier's name of 1702. Francisco Hernández de Toledo, Royal Physician, records tlilxochitl in his material medica De rerum medicarum Novae Hispaniae Thesaurus, precisely the edition by the Accademia dei Lincei in Rome 1628 and gives it the name Araco aromatico with a description and use. Clusius in 1602 calls it Lobus largus aromaticus in
Rariorum plantarum historia. Andrews, who described V. planifolia (Bot. Repository, for new, and rare plants 8: pl. 538. 1808) writes for the protologue and type: "the finest specimen in England and the only one that has blossomed, is in the choice collection of the Right Hon. Charles Greville, at Paddington, from which our drawing was taken. We are informed that it is native of the West Indies, and was introduced to this country by the Marquis of Blanford". All indicates that the Codex contains the earliest iconography of this orchid genus and species.

In Hernandez' Rerum medicarum... Tesoro Messicani, Liber Secundum, Aromata Promit, on page 38 of the 1651 final edition, tlilxochitl is very accurately 
illustrated, perhaps the second oldest depiction of the genus (Fig. 2).

AcKnowledgements. My thanks to Mahmood Sasa who presented me with the 1996 Mexican facsimilar edition of the Libellus. Rebeca Brenes for help in the editing of the final version of this paper. Neal Smith and Carlos Ossenbach made insightful suggestions to the earlier version of this paper as did two anonymous reviewers.

\section{LiterATURE CITED}

Anselmi, A. 2007. Il diario del viaggio in Spagna del Cardinale Francesco Barberini scritto da Cassiano dal Pozzo. Doce Calles, Madrid..

Arévalo C., C. 1935. Bernardo de Cienfuegos y la botica española de su época. Estudios sobre la ciencia española del siglo XVII. Graf. Universal, Madrid, pp. 323-335.

Borgia S., F. 1944. El primer colegio de América, Sta. Cruz de Tlatelolco, con un estudio del Códice de Tlatelolco. Historia de la literatura nahuatl. México, 2 vols.

Breedlove, D.E. \& R. Laughlin. 1993. The flowering of man: a Tzotzil botany of Zinacantán. Smithsonian Contributions to Anthropology, 35.

Byland, B. 2000. An Aztec herbal: the classic codex of 1552. Dover.

Díaz, J.L. 1976. Indice y sinonímia de las plantas medicinales de Mexico. Mon. Cient. I. Centro de Estudios Económicos y Sociología del Tercer Mundo.

Emmart, E. 1935. Concerning the Badianus manuscript. An Aztec herbal Codex Barberini Latin 241. Smithsonian Institution.

Durazo, Q., Humate, J., Somolinos, P., Lozoya, X., Viesca, C. 1991. El regreso del Códice de la Cruz-Badiano a México. Gaceta Médica Mexicana 127(1): 105-117.

Emmart, E. (ed.) 1940. The Badianus manuscript (Codex Barberini, Latin 241). An Aztec Herbal of 1552. Johns Hopkins.

Fernández, J. 1964. Miniaturas del Código de la CruzBadiano. Gaceta Medica Mexicana 94: 1179-1184.

Gabrieli, G. 1880. Contributti alla storia della Accademia dei Lincei. Roma, 2 vols.

Gabrieli, G. 1929. Iconografia botanica. Due codici iconografici di piante miniati nella Biblioteca Reale di Windsor. Recond. Della Reale Accad. Dei Lincei, ser. $6^{\text {a }}$, $\mathrm{X}(10):$ 531-538.

Garibay, M.A. 1996. Nombres nahuas en el Códice de la Cruz-Badiano. Sentido etimológico. Apéndice B. pp 223-234. Libellus... edición del Fondo de Cultura Económica, México.

Gates, W. 1939. The de la Cruz-Badiano Aztec herbal. The
Maya Society, Baltimore, Publications 22, 23.

Goodman, D. 1990. Poder y penuria.Gobierno, Tecnología y Ciencia en la España de Felipe II. Alianza Universitaria, Madrid.

Guerrini, L. 2008. The Accademia dei Lincei and the New World. Max Planck Inst. F. Wissenschaftsgeschichte. 348.

Keen, B. 1999. The Aztec image in Western thought. Rutgers.

Langenheim, J. 2003. Plant resins. Chemistry, evolution, ecology, ethnobotany. Timber Press. Portland.

León Portilla, M. 2002. Bernardino de Sahagún. First Anthropologist. Oklahoma.

Mason, ap. 2004. The lives of images. Reaction Books.

Major, M.V. 1931. The Barberini Library. Library Review 3(4): 164-170.

Martínez M, J. 1994. La Corte de Felipe II. Alianza Universitaria, Madrid. Pp. 73-105.

Miranda, F. \& J. Valdés. 1964. Comentarios botánicos del Códice de la Cruz- Badiano. Gaceta Médica Mexicana 94: 1185-1187.

Miranda, F. \& Valdés, J. 1996. Comentarios botánicos. Reimpresión del Libellus... Fondo de Cultura Económica, México. Pp. 107-148.

Pincherle , A. 1952. La dignita dell'uomo e l'indigeno americano. Atti Cong. Int. di Studi Umanistici 1952, Roma.

Reko, L. 1947. Nombres botánicos del Manuscrito Badiano. Bol. Soc. Bot. Méx. 5: 23-43.

Rey B., M. 2004. Juntas de herbolarios y tertulias espagíricas: el círculo cortesano de Diego de Cortavila (1597-1657). Acta Hisp. Med. Scientia Hist. Illustranda 24: 243-267.

Robertson, D. 1959. Mexican manuscript painting of the early colonial period. Metropolitan Schools, Yale.

Sharp, F. 2005. Medical remedies: from the old to the new. ANZ J. of Surgery 75(5): 340-346.

Somolinos D., G 1964. La cultura Azteca en el siglo XVI. Gaceta Médica de México 94:1165-1170.

Somolinos D. G, 1996. Estudio histórico. En reimpresión del Libellus... Fondo de Cultura Económica, México. Pp. 165-187.

Somolinos D., G. 1996. Bibliografía de copias, traslados y ediciones. En Libellus..., reimpresión de Fondo de Cultura económica, México. Pp. 217-222.

Stolz, A.M. 1964. Descripción del Códice. Estudios y comentarios del Libellus... Instituto del Seguro Social, México. Pp. 229-236.

Stross, B. 1997. Mesoamerican copal resins. U-Mut Maya 6: 177-186. 
Thorndike, L. 1929-30. Vatican Latin Manuscripts in the History of Science and Medicine. Isis 8: 53-102.

Viesca, C. 1992. El Libellus... y su contexto histórico. Estudios actuales sobre el Libellus... Secretaría de Salud, México.
Zetina, S., Ruvalcaba J, Falcón T, Hernández E., González C., Arroyo E., López M. 2008. Painting syncretism: a non-destructive análisis of the Badiano Codex. $9^{\text {th }}$ Intl. Congr. On NDA of Art, Jerusalem, Mayo 2008: 1-10. 